\title{
A mechanism for production of hydroxyl radicals by the brown-rot fungus Coniophora puteana: Fe(III) reduction by cellobiose dehydrogenase and $\mathrm{Fe}$ (II) oxidation at a distance from the hyphae
}

\author{
Simon M. Hyde and Paul M. Wood
}

\begin{abstract}
Author for correspondence: Paul M. Wood. Tel: +44 117928 8594. Fax: +44 1179288274. e-mail: p.wood@bris.ac.uk
\end{abstract}

Department of Biochemistry, University of Bristol, Bristol BS8 1TD, UK

\begin{abstract}
In timber infested by brown-rot fungi, a rapid loss of strength is attributed to production of hydroxyl radicals $\left(\mathrm{HO}^{\circ}\right)$. The hydroxyl radicals are produced by the Fenton reaction [ $\mathrm{Fe}(\mathrm{II}) / \mathrm{H}_{2} \mathrm{O}_{2}$ ], but the pathways leading to $\mathrm{Fe}(\mathrm{II})$ and $\mathrm{H}_{2} \mathrm{O}_{2}$ have remained unclear. Cellobiose dehydrogenase, purified from cultures of Coniophora puteana, has been shown to couple oxidation of cellodextrins to conversion of $\mathrm{Fe}$ (III) to Fe(II). Two characteristics of brown rot are release of oxalic acid and lowering of the local pH, often to about pH 2. Modelling of Fe(II) speciation in the presence of oxalate has revealed that Fe(II)-oxalate complexes are important at pH 4-5, but at pH 2 almost all Fe(II) is in an uncomplexed state which reacts very slowly with dioxygen. Diffusion of Fe(II) away from the hyphae will promote conversion to $\mathrm{Fe}(\mathrm{II})$-oxalate and autoxidation with $\mathrm{H}_{2} \mathrm{O}_{2}$ as product. Thus the critical Fe(II)/ $\mathrm{H}_{2} \mathrm{O}_{2}$ combination will be generated at a distance, enabling hydroxyl radicals to be formed without damage to the hyphae.
\end{abstract}

Keywords: cellobiose dehydrogenase, Coniophora puteana, free radicals, oxalate, wood decay

\section{INTRODUCTION}

Most wood-rotting fungi can be placed in one of three physiological classes: white rot, soft rot and brown rot (Eriksson et al., 1990). The white-rot fungi degrade all components of lignocellulose, while soft rots merely cause a gradual softening at wet surfaces. Decay by brown rot leads to mineralization of polysaccharides, but lignin is not solubilized and remains as an amorphous brown residue. The fungi in this class include Coniophora puteana ('cellar rot') and Serpula lacrymans (dry rot). Early studies noted a rapid loss of strength prior to loss in weight, leading to the designation 'destruction rot' by Falck (1926). This physical change correlates with cleavage of cellulose into crystallites of about 200 glucose residues (Cowling, 1961). A closer examination revealed that degradation

Abbreviations: $\mathrm{CDH}$, cellobiose dehydrogenase (EC 1.1.99.18); $D C P I P$ 2,6-dichlorophenol-indophenol. was taking place in an inner layer of the wood cell wall (the $S_{2}$ layer) while the layer adjacent to the hyphae $\left(S_{3}\right)$ remained apparently unchanged (Wilcox, 1968; Eriksson et al., 1990). Cowling \& Brown (1969) deduced that the causative agent must be smaller than an enzyme, because of the limited size of the wood pores.

The hydroxyl radical is the strongest oxidizing agent in aqueous systems (Wood, 1988). Its standard biological source is the reaction of many forms of $\mathrm{Fe}$ (II) with $\mathrm{H}_{2} \mathrm{O}_{2}$ (the Fenton reaction):

$\mathrm{Fe}^{2+}+\mathrm{H}_{2} \mathrm{O}_{2} \rightarrow \mathrm{Fe}^{3+}+\mathrm{HO}^{\circ}+\mathrm{HO}^{-}$

Koenigs $(1974 \mathrm{a}, \mathrm{b})$ presented a detailed comparison of the effects of Fenton's reagent and brown rot on wood. The similarities led him to propose that the early stages of brown rot involve production of hydroxyl radicals. For cellulose, hydroxyl radicals and brown rot fungi both cause selective cleavage within non-crystalline regions and an increased content of carbonyl and carboxyl groups (Highley, 1977; Kirk et al., 1991). As 
more direct evidence, the EPR spectrum of an $\mathrm{HO}^{-}$ adduct has been observed after incubation of Poria placenta with the spin-trap 5,5-dimethylpyrroline- $\mathrm{N}$ oxide (DMPO) (Illman et al., 1989). Moreover, growth of C. puteana and other brown rots in the presence of phthalic hydrazide led to formation of a 3-hydroxy derivative, as expected for attack by $\mathrm{HO}^{\circ}$ on the aromatic ring (Backa et al., 1992).

A characteristic feature of brown rots is secretion of oxalic acid, leading to a marked lowering of the local $\mathrm{pH}$. The production of oxalic acid was first noted by Shimazono (1955), while data for C. puteana are provided by Evans et al. (1990). Reported concentrations include 5-7 mM for Poria placenta and Wolfiporia cocos with pine holocellulose as carbon source (Green $e t$ al., 1991; Espejo \& Agosin, 1991) and higher values of 22-25 $\mathrm{mM}$ in the presence of glucose (Espejo \& Agosin, 1991; Dutton et al., 1993). As a working hypothesis, the present study has assumed an oxalate concentration of $10 \mathrm{mM}$. The $\mathrm{pH}$ of wood itself is generally in the range 4-6 (Rayner \& Boddy, 1988). However, measurements taken with a $\mathrm{pH}$ microprobe for pine-wood infected by P. placenta indicated a fall to between $\mathrm{pH} 1.7$ and 2.5 (Green et al., 1991). There are many other reports of pHs close to 2.5 after growth of brown rots (Dutton $e t$ al., 1993; Espejo \& Agosin, 1991; Micales \& Highley, 1989). Such low pHs can be explained by the secretion of oxalic acid, given its exceptional strength as an organic acid $\left(\mathrm{pK}_{1}=1 \cdot 1\right)$. Oxalate is also a moderately strong iron chelator $\left[K=10^{20}\right.$ for $\mathrm{Fe}^{3+}+3 \mathrm{ox}^{2-} \leftrightarrow \mathrm{Fe}(\mathrm{ox})_{3}^{3-}$; see below]. In the absence of evidence to the contrary, we have assumed that oxalate is the physiological iron chelator for C. puteana.

The flavohaemoprotein cellobiose dehydrogenase $(\mathrm{CDH})$ has been reported from a wide range of woodrotting fungi (Morpeth, 1991; Bao et al., 1993). It oxidizes the reducing end of cellodextrins, with substrates extending upwards in size from cellobiose to cellulose itself (Kremer \& Wood, 1992a):

$\beta$-D-cellobiose $\rightarrow$ D-cellobionolactone $+2 \mathrm{e}^{-}+2 \mathrm{H}^{+}$

$\mathrm{CDH}$ was first purified from C. puteana by Schmidhalter \& Canevascini (1993). Postulated roles in other fungi include prevention of snap-back (i.e. making the cellulase reaction irreversible) and reduction of oxidized aromatic species during lignin degradation by white-rot fungi (Ander, 1994). However, CDH can also couple cellodextrin oxidation to reduction of $\mathrm{Fe}$ (III) (Kremer \& Wood, 1992b). Indeed, the presence of a haem group with axial ligands as for mitochondrial cytochrome $c$ (Cox et al., 1992) makes it well fitted for a singleelectron reduction.

The aim of this work was to attempt to answer the following three questions, in the context of hydroxyl radical production by brown rots:

- How is $\mathrm{Fe}$ (III) reduced to $\mathrm{Fe}$ (II) ?

- How is $\mathrm{O}_{2}$ reduced to $\mathrm{H}_{2} \mathrm{O}_{2}$ ?

- How can the fungus avoid being killed by the unspecific reactivity of these radicals?

\section{METHODS}

Organism, enzyme purification and assay. C. puteana (strain PRL-11R, from the Building Research Establishment, Watford, UK) was grown at $26^{\circ} \mathrm{C}$ as described by Schmidhalter \& Canevascini (1992). The preculture stage was stationary, with $50 \mathrm{ml}$ medium in $250 \mathrm{ml}$ flasks for $8 \mathrm{~d}$. The main culture had $1 \%(\mathrm{w} / \mathrm{v}$ ) amorphous cellulose (phosphoric acid treated Avicel) as additional carbon source; four precultures were added to $650 \mathrm{ml}$ medium in a $21 \mathrm{flask}$, which was then shaken at 150 r.p.m. for $12 \mathrm{~d}$. CDH was assayed as described for Phanerochaete chrysosporium, assuming $\varepsilon_{\text {peak-trough }}=118 \mathrm{mM}^{-1} \mathrm{~cm}^{-1}$ in cellobiose-minus-untreated difference spectra, scanned from 440 to $400 \mathrm{~nm}$ (Kremer \& Wood, 1992b). Its purification was based on Schmidhalter $\&$ Canevascini (1993), including DEAE-Sepharose with a gradient of $0-250 \mathrm{mM} \mathrm{NaCl}$ at $\mathrm{pH} 6.5(10 \mathrm{mM}$ phosphate buffer), and gel filtration with Sephacryl S-200 (500 ml; pH 6.5).

Materials. $\mathrm{Fe}$ (II) was added as $\mathrm{Fe}$ (II) sulphate, dissolved in deionized water on the day of use; $\mathrm{Fe}$ (III) was added as $\mathrm{Fe}$ (III) chloride. Ferricyanide was assayed by measuring $A_{420}$ $\left[\varepsilon_{420}=1.04 \mathrm{mM}^{-1} \mathrm{~cm}^{-1}\right.$ (Kremer \& Wood, 1992b) ], and Fe(III) oxalate by measuring $A_{340}\left[\varepsilon_{340}=1.6 \mathrm{mM}^{-1} \mathrm{~cm}^{-1}\right.$ in $10 \mathrm{mM}$ oxalate $(\mathrm{pH} 4 \cdot 0)]$.

Oxygen electrode, redox potentials. $\mathrm{O}_{2}$ electrode and redox potential measurements were as described by Kremer \& Wood (1992b).

Hydroxyl radical detection. Hydroxyl radicals were detected by salicylic acid hydroxylation as described by Kremer \& Wood (1992c). The reaction mixture was quenched with $\mathrm{HCl}$. Aromatics were then extracted in ethyl acetate, evaporated to dryness and redissolved in water. For HPLC, a $50 \mu \mathrm{l}$ sample was injected into a $25 \mathrm{~cm}$ Spherisorb reverse-phase ODS column. The eluant was $97 \cdot 2 \%$ citrate/acetate buffer (pH 4.75$)$ plus $2.8 \%(\mathrm{v} / \mathrm{v})$ methanol. Detection was by absorbance at $308 \mathrm{~nm}$.

Speciation calculations. Chemical speciation calculations were conducted with the MINTEQA2 computer program (Allison et al., 1990), which includes correction for ionic strength using the Davies equation (Davies, 1962):

$I=\frac{1}{2} \sum\left(Z_{i}^{2} C_{i}\right)$

$\log \gamma_{1}=0.509 Z_{i}^{2}\left\{\left[I^{\frac{1}{2}} /\left(1+I^{\frac{1}{2}}\right)\right]-0.24 I\right\}$

where $C_{i}$ is the concentration and $\gamma_{i}$ the activity coefficient of an ion with charge $Z_{i}$, and $I$ is ionic strength.

Table 1 shows the relevant stability constants as published and after correction to $I=0$ for insertion in MINTEQA2. The table uses the standard notation for equilibrium constants: $K_{1}=\mathrm{ML} /(\mathrm{M} . \mathrm{L}), \beta_{2}=\mathrm{ML}_{2} /\left(\mathrm{M} . \mathrm{L}^{2}\right)$ and $\beta_{3}=\mathrm{ML}_{3} /\left(\mathrm{M} . \mathrm{L}^{3}\right)$, where $M$ is the cation and $L$ is the ligand (in this case, oxalate $\left.^{2-}\right)$. The $\mathrm{Fe}(\mathrm{III})$ and $\mathrm{Fe}(\mathrm{II})$ speciations were evaluated for $10 \mathrm{mM}$ oxalate [i.e. $10 \mathrm{mM}$ total concentration of oxalate in the form of $\mathrm{ox}^{2-}$, $\mathrm{Hox}^{-}, \mathrm{H}_{2} \mathrm{ox}$, and $\mathrm{Fe}^{\mathrm{II}}(\mathrm{ox})_{n}$ or $\mathrm{Fe}^{\mathrm{III}}(\mathrm{ox})_{n}$ complexes], ionic strength $0.05 \mathrm{M}$ and $25^{\circ} \mathrm{C}$. Total $\mathrm{Fe}$ (III) or $\mathrm{Fe}$ (II) was set at $10^{-6} \mathrm{M}$, giving results that are valid for any iron concentration, provided there is a large excess of uncomplexed oxalate (i.e. ox ${ }^{2-}, \mathrm{Hox}^{-}$and $\mathrm{H}_{2} \mathrm{Ox}$ ) relative to iron. The input included equilibrium constants for $I \rightarrow 0$ from Table 1. Species arising from $\mathrm{Fe}^{3+}$ and $\mathrm{Fe}^{2+}$ hydrolysis [e.g. $\mathrm{Fe}^{\mathrm{II}}(\mathrm{OH})^{+}$and $\left.\mathrm{Fe}^{\mathrm{III}}(\mathrm{OH})^{2+}\right]$ were included in the program but were not significant. Redox potentials for $\mathrm{Fe}^{\mathrm{III}}(\mathrm{ox})_{n} / \mathrm{Fe}^{\mathrm{II}}(\mathrm{ox})_{n}$ couples were calculated from

$E^{0}\left(\mathrm{Fe}^{\mathrm{III}} / \mathrm{Fe}^{\mathrm{II}}\right)=E^{0}\left(\mathrm{Fe}^{3+} / \mathrm{Fe}^{2+}\right)$ $-(2 \cdot 303 R T / F)\left(\log \mathrm{K}_{\mathrm{Fe}(\mathrm{III})}-\log \mathrm{K}_{\mathrm{Fe}(\mathrm{II})}\right)$, 
Table 1. Equilibrium constants for computation of speciation

\begin{tabular}{|lccccc|}
\hline Species & $\begin{array}{c}\text { Equilibrium } \\
\text { constant }(K) \\
\text { in standard } \\
\text { notation }\end{array}$ & $\begin{array}{c}\text { log } K \text { as } \\
\text { measured }\end{array}$ & $\begin{array}{c}\text { Ionic } \\
\text { strength } \\
(I), \\
\text { temp. }\end{array}$ & $\begin{array}{c}\log K \\
\text { corrected } \\
\text { to } I \rightarrow 0\end{array}$ & Reference* $^{*}$ \\
\hline $\mathrm{Hox}^{-}$ & $K_{1}$ & & $0,25^{\circ} \mathrm{C}$ & $4 \cdot 266$ & 1 \\
$\mathrm{H}_{2} \mathrm{ox}$ & $\beta_{2}$ & & $0,25^{\circ} \mathrm{C}$ & $5 \cdot 518$ & 1 \\
$\mathrm{Fe}^{\mathrm{II}}(\mathrm{ox})^{0}$ & $K_{1}$ & $3 \cdot 05$ & $1 \cdot 0,25^{\circ} \mathrm{C}$ & $4 \cdot 21$ & 1,2 \\
$\mathrm{Fe}^{\mathrm{II}}(\mathrm{ox})_{2}^{2-}$ & $\beta_{2}$ & $5 \cdot 01$ & $1 \cdot 0,25^{\circ} \mathrm{C}$ & 6.07 & 2 \\
$\mathrm{Fe}^{\mathrm{II}}(\mathrm{ox})_{3}^{4-}$ & $\beta_{3}$ & $5 \cdot 22$ & $0 \cdot 5,25^{\circ} \mathrm{C}$ & $5 \cdot 22$ & 3 \\
$\mathrm{Fe}^{\mathrm{III}}(\mathrm{ox})^{+}$ & $K_{1}$ & $7 \cdot 53$ & $0 \cdot 5,25^{\circ} \mathrm{C}$ & $9 \cdot 33$ & 4 \\
$\mathrm{Fe}^{\mathrm{III}}(\mathrm{ox})_{2}^{-}$ & $\beta_{2}$ & 13.64 & $0 \cdot 5,25^{\circ} \mathrm{C}$ & 16.0 & 4 \\
$\mathrm{Fe}^{\mathrm{III}}(\mathrm{ox})_{3}^{3-}$ & $\beta_{3}$ & 18.49 & $0 \cdot 5,25^{\circ} \mathrm{C}$ & 20.3 & 4 \\
\hline
\end{tabular}

*References: 1, Martell \& Smith (1977); 2, Micskei (1987); 3, Schaap et al. (1954); 4, Deneux et al. (1968).

assuming $E^{0}\left(\mathrm{Fe}^{3+} / \mathrm{Fe}^{2+}\right)=+0.771 \mathrm{~V}$ for uncomplexed iron (Bard, 1982) and equilibrium constants for $I \rightarrow 0$.

\section{RESULTS}

\section{Absence of spontaneous decomposition for Fe(III) oxalate}

In a widely cited study, Schmidt et al. (1981) claimed that $\mathrm{Fe}$ (II) is produced by spontaneous decomposition of $\mathrm{Fe}$ (III) oxalate (see Kirk, 1983). We examined this reaction with use of a $\mathrm{Pt}$ electrode to monitor the $\mathrm{Fe}(\mathrm{III}) / \mathrm{Fe}$ (II) redox potential. As shown in Fig. 1, a redox potential that was stable in darkness showed a sharp decline on exposure to diffuse daylight, implying photolytic conversion of $\mathrm{Fe}$ (III) to $\mathrm{Fe}$ (II). Similar results were obtained at $\mathrm{pH} 2$ or $\mathrm{pH} 4 \cdot 5$. Thus it would seem

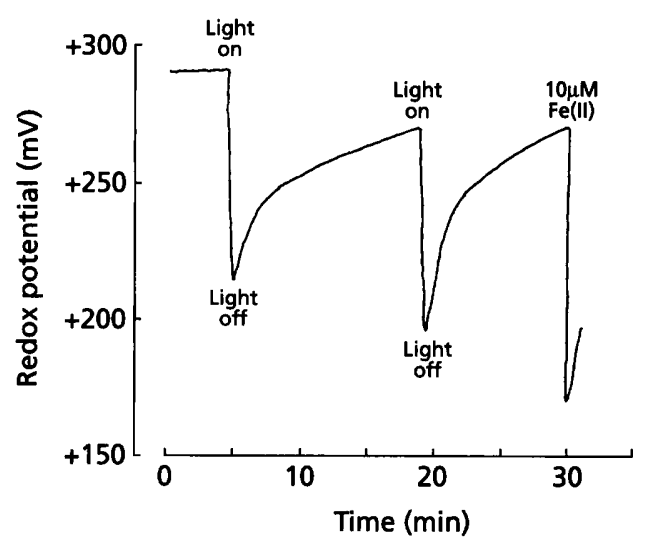

Fig. 1. Light-induced decomposition of $\mathrm{Fe}(\mathrm{III})$ oxalate monitored by redox potentiometry. The medium was airequilibrated $20 \mathrm{mM}$ oxalic acid/potassium oxalate, $\mathrm{pH} 4 \cdot 0$, plus $30 \mathrm{mM} \mathrm{KCl}$ and $1 \mathrm{mM} \mathrm{Fe}$ (III), added as $\mathrm{FeCl}_{3}$. The light source was diffuse daylight. The upward rise in potential in darkness is caused by $\mathrm{Fe}(\mathrm{II})$ autoxidation by dissolved $\mathrm{O}_{2}$.

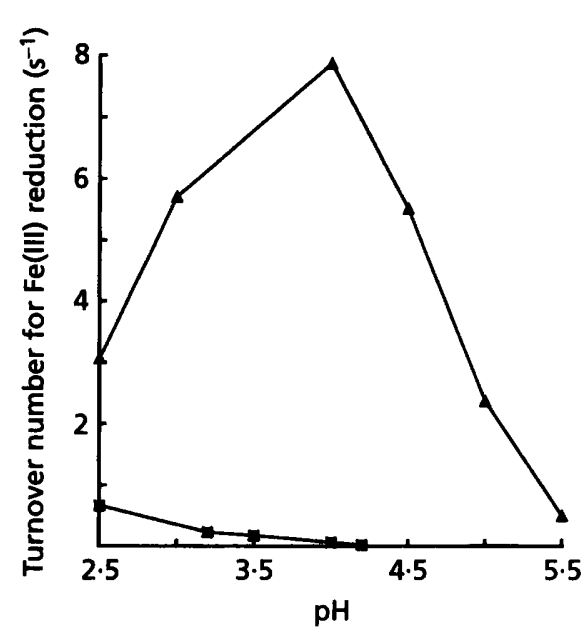

Fig. 2. Ferricyanide and Fe(III) oxalate reduction by $\mathrm{CDH}$ as a function of $\mathrm{pH}$. The reduction was monitored spectrophotometrically at $30^{\circ} \mathrm{C}$, using a wavelength of $420 \mathrm{~nm}$ for ferricyanide and $340 \mathrm{~nm}$ for $\mathrm{Fe}$ (III) oxalate. $\mathrm{O}_{2}$ was previously removed by bubbling with Ar. For ferricyanide reduction, $500 \mu \mathrm{M}$ ferricyanide and $500 \mu \mathrm{M}$ cellobiose were added to $50 \mathrm{mM}$ citric acid/sodium citrate buffer at the appropriate $\mathrm{pH}$. Experiments with Fe(III) oxalate used $10 \mathrm{mM}$ oxalic acid/potassium oxalate buffer, with $1 \mathrm{mM}$ cellobiose and $500 \mu \mathrm{M} \mathrm{Fe}$ (III) added as $\mathrm{Fe}^{\mathrm{III}} \mathrm{Cl}_{3}$. $\mathrm{CDH}$ was present at $0.5 \mu \mathrm{M}$. Rates obtained from duplicate experiments are expressed as turnover numbers, i.e. [ $\mu \mathrm{mol} \mathrm{Fe}(\mathrm{III})$ reduced] $\mathrm{s}^{-1}(\mu \mathrm{mol} \mathrm{CDH})^{-1}$. $\Delta$, Ferricyanide; $\mathbf{\square}$, Fe(III) oxalate.

that Schmidt et al. (1981) observed a photochemical decomposition, as discussed below.

\section{Cellobiose dehydrogenase as a source of Fe(II)}

Schmidhalter \& Canevascini (1993) only reported activity for CDH from C. puteana with DCPIP (a quinone analogue) as acceptor. We examined its reduction of $\mathrm{Fe}(\mathrm{III})$ (Fig. 2). Initial studies used ferricyanide, as a 


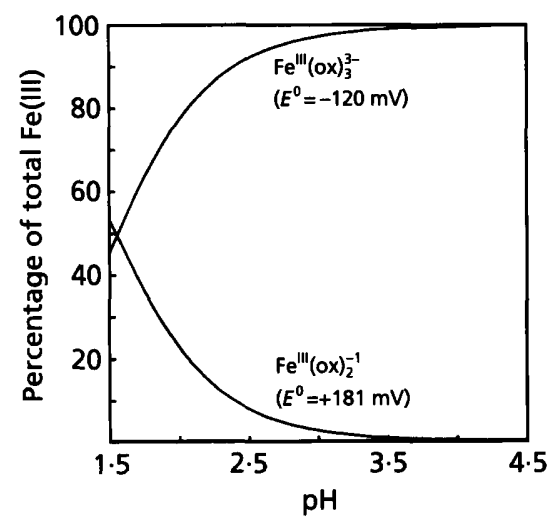

Fig. 3. Fe(III) oxalate speciation as a function of $\mathrm{pH}$. The speciation was calculated for $10 \mathrm{mM}$ total oxalate, $I=0.05$, $25^{\circ} \mathrm{C}$ using MINTEQA2. The following species were always less than $1 \%$ of the total and are therefore not shown: $\mathrm{Fe}^{3+}$, $\mathrm{Fe}^{\mathrm{III}}(\mathrm{ox})^{+}[1 \cdot 1 \%$ at $\mathrm{pH} 1 \cdot 5]$.

model $\mathrm{Fe}$ (III) complex with a high, $\mathrm{pH}$-independent redox potential. The absolute rates and $\mathrm{pH}$ dependence were very similar to earlier studies with $\mathrm{CDH}$ from the white-rot fungus $P$. chrysosporium (Kremer \& Wood, $1992 b, c)$. Fig. 2 also shows data for Fe(III) oxalate reduction, obtained under anaerobic conditions to prevent reoxidation of $\mathrm{Fe}(\mathrm{II})$. $\mathrm{Fe}$ (III) oxalate was reduced by $\mathrm{CDH}$, although at a much lower rate than for ferricyanide. The reduction showed a very acid $\mathrm{pH}$ optimum.

An explanation for this behaviour with $\mathrm{Fe}$ (III) oxalate was revealed by modelling $\mathrm{Fe}(\mathrm{III})$ speciation as a function of $\mathrm{pH}$, as shown in Fig. 3. Above $\mathrm{pH} 3$, almost all $\mathrm{Fe}$ (III) is complexed by three oxalates to form $\mathrm{Fe}^{\mathrm{III}}(\mathrm{ox})_{3}^{3-}$, which has a calculated one-electron redox potential of $-120 \mathrm{mV}$, far below the value of $+165 \mathrm{mV}$ measured for $\mathrm{CDH}$ from $P$. chrysosporium at $\mathrm{pH} 4$ (Kremer \& Wood, 1992b). This complex is therefore almost certainly not reducible by $\mathrm{CDH}$. As the $\mathrm{pH}$ is lowered, a complex with two oxalates becomes more important, $\mathrm{Fe}^{\mathrm{III}}(\mathrm{ox})_{2}^{1-}$. This has a one-electron potential of $+181 \mathrm{mV}$, allowing reduction by $\mathrm{CDH}$ to take place.

\section{Production of Fenton's reagent by Fe(II) autoxidation}

Many forms of $\mathrm{Fe}(\mathrm{II})$ are autoxidizable, implying reaction with dioxygen by one-electron transfer:

$\mathrm{Fe}^{2+}+\mathrm{O}_{2} \leftrightarrow \mathrm{Fe}^{3+}+\mathrm{O}_{2}^{--}$

The superoxide formed by (2) is rapidly removed by reaction with $\mathrm{Fe}(\mathrm{II})$ (Brown \& Mazzarella, 1987):

$\mathrm{Fe}^{2+}+\mathrm{O}_{2}^{--}+2 \mathrm{H}^{+} \rightarrow \mathrm{Fe}^{3+}+\mathrm{H}_{2} \mathrm{O}_{2}$

Thus $\mathrm{Fe}(\mathrm{II})$ autoxidation creates $\mathrm{H}_{2} \mathrm{O}_{2}$. Moreover, partial autoxidation creates the $\mathrm{Fe}(\mathrm{II}) / \mathrm{H}_{2} \mathrm{O}_{2}$ combination required for hydroxyl radical production (Zepp et al., 1992; Wood, 1994). Evidence for $\mathrm{HO}^{\circ}$ production during autoxidation of $\mathrm{Fe}$ (II) oxalate was obtained by

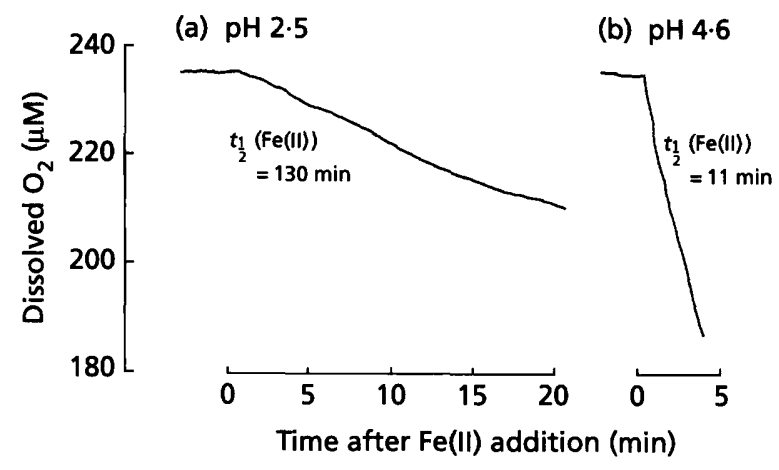

Fig. 4. $\mathrm{Fe}(\mathrm{II})$ oxalate autoxidation kinetics studied with an $\mathrm{O}_{2}$ electrode. The buffer was $10 \mathrm{mM}$ oxalic acid/potassium oxalate at $30^{\circ} \mathrm{C} ; 1 \mathrm{mM} \mathrm{Fe}(\mathrm{II})$ was added at zero time. The $t_{1 / 2}$ for $\mathrm{Fe}(\mathrm{II})$ was calculated from the initial $\mathrm{O}_{2}$ uptake rate, assuming firstorder kinetics and $1 \mathrm{O}_{2} \equiv 4 \mathrm{Fe}$ (II).

the standard test of salicylate conversion to 2,3- and 2,5dihydroxybenzoate (Grootveld \& Halliwell, 1986) (results not shown). Thus the mere presence of Fe(II) oxalate in aerobic solution can lead to hydroxyl radicals, without the need for any separate source of $\mathrm{H}_{2} \mathrm{O}_{2}$.

\section{$\mathrm{Fe}($ II) lifetime before autoxidation}

The rate of autoxidation can be monitored continuously with an oxygen electrode, as shown in Fig. 4. An approximate rate of $\mathrm{Fe}$ (II) oxidation can be deduced from such experiments, since $\mathrm{Fe}(\mathrm{II}): \mathrm{O}_{2}$ stoichiometries of between 3 and 4 have been obtained with a variety of organic chelators (Burkitt \& Gilbert, 1991). The kinetics have been studied for many other $\mathrm{Fe}$ (II) complexes, and show a dependence on $\mathrm{Fe}$ (II) that lies between first order (rate proportional to [Fe(II)]) and second order (rate proportional to $\left.[\mathrm{Fe}(\mathrm{II})]^{2}\right)$, depending on the relative rates of reactions (2) and (3) (Brown \& Mazzarella, 1987). In the absence of detailed information, a lower limit for the $\mathrm{Fe}$ (II) half-life $\left(t_{\frac{1}{2}}\right)$ can be deduced from the initial rate of $\mathrm{O}_{2}$ uptake, by ignoring the second-order component and assuming an $\mathrm{Fe}(\mathrm{II}): \mathrm{O}_{2}$ stoichiometry of 4. For $30^{\circ} \mathrm{C}, 10 \mathrm{mM}$ oxalate (as shown), the $\mathrm{Fe}$ (II) halflife at $\mathrm{pH} 2.5$ was about $130 \mathrm{~min}$. The rate of oxidation became sharply faster as the $\mathrm{pH}$ was increased, with an estimated half-life for $\mathrm{Fe}$ (II) of about $11 \mathrm{~min}$ at $\mathrm{pH} 4.6$ (Fig. 4b). At lower temperatures, or with less oxalate, the $\mathrm{Fe}$ (II) half-life would be longer than these values.

Again, the reason for the sharp $\mathrm{pH}$ dependence was revealed by an analysis of speciation (Fig. 5). For $10 \mathrm{mM}$ oxalate, uncomplexed $\mathrm{Fe}^{2+}$ predominates at $\mathrm{pH} 2$. As the $\mathrm{pH}$ is increased, the dominant species becomes $\mathrm{Fe}^{\mathrm{II}}(\mathrm{ox})^{0}$. These species have one-electron $\mathrm{Fe}^{\mathrm{III}} / \mathrm{Fe}^{\mathrm{II}}$ redox potentials of +771 and $+468 \mathrm{mV}$ respectively, and for thermodynamic reasons cannot be autoxidizable, as discussed by Wood (1994) for ferrocyanide $\left(E^{0}=+430 \mathrm{mV}\right)$. However, a $\mathrm{pH}$ increase from 2.5 to 4.5 also causes a dramatic increase in the proportion complexed by two oxalates, $\mathrm{Fe}^{\mathrm{II}}(\mathrm{ox})_{2}^{2-}$. This has a lower 


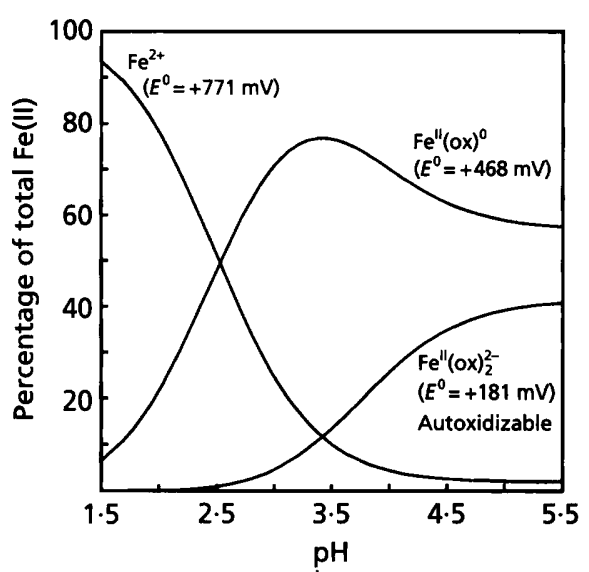

Fig. 5. $\mathrm{Fe}$ (II) oxalate speciation as a function of $\mathrm{pH}$. The speciation was calculated for $10 \mathrm{mM}$ total oxalate, $I=0.05$, $25^{\circ} \mathrm{C}$ using MINTEQA2. Fe" $(\mathrm{ox})_{3}^{4-}$ was always less than $1 \%$ of the total and is therefore not shown.

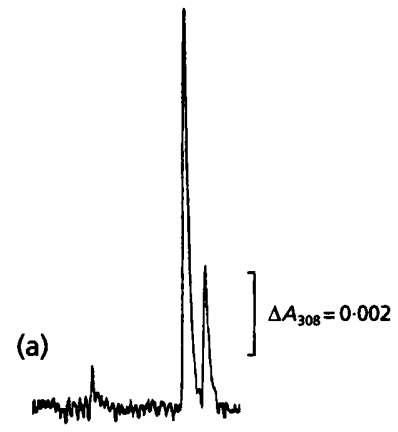

(b)

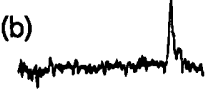

(c)

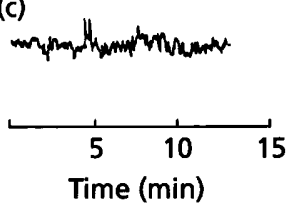

Fig. 6. Reduction of $\mathrm{Fe}(\mathrm{III})$ oxalate by $\mathrm{CDH}$ as a source of hydroxyl radicals. HPLC profiles obtained after $1 \mathrm{~h}$ incubations at $30^{\circ} \mathrm{C}$ are shown. (a) Salicylate hydroxylation by Fenton's reagent: $3.3 \mathrm{mM} \mathrm{H}_{2} \mathrm{O}_{2}$ and $1 \mathrm{mM} \mathrm{Fe}$ (II) were added to $10 \mathrm{mM}$ oxalate buffer, $\mathrm{pH} 3.5$, plus $2 \mathrm{mM}$ salicylate. (b) Evidence for HO production by $\mathrm{CDH}: 1 \mu \mathrm{M} \mathrm{CDH}, 500 \mu \mathrm{M}$ cellobiose and $50 \mu \mathrm{M} \mathrm{Fe}$ (III) were added to $10 \mathrm{mM}$ oxalate buffer (pH 3.5) plus $2 \mathrm{mM}$ salicylate. (c) Absence of $\mathrm{HO}^{\circ}$ production with catalase present. The conditions were as in (b), apart from addition of 140 units of catalase (assayed as in Kremer \& Wood, 1992c). The timescale is with zero at the time of injection. Elution of salicylate took more than $15 \mathrm{~min}$ and is not shown.

redox potential of $+181 \mathrm{mV}$, which is consistent with the observed rate of autoxidation. [As a comparison, $\mathrm{Fe}$ (II) EDTA, which reacts fast with $\mathrm{O}_{2}$, has a redox potential of $+114 \mathrm{mV}$ (Wood, 1994).]

\section{CDH as a source of hydroxyl radicals}

The ability of $\mathrm{CDH}$ to reduce $\mathrm{Fe}$ (III) leads to the prediction that it should be capable of producing hydroxyl radicals, if present together with a cellodextrin substrate, $\mathrm{Fe}(\mathrm{III})$ and dissolved $\mathrm{O}_{2}$. This was demonstrated by Kremer \& Wood (1992c) with CDH from $P$. chrysosporium plus cellobiose, using $\mathrm{Fe}(\mathrm{III})$ acetate as an initial model system. For Fe oxalate, the speciation plots in Figs 3 and 5 show that there is no $\mathrm{pH}$ at which $\mathrm{Fe}$ (III) reduction and $\mathrm{Fe}$ (II) autoxidation will both be fast. Nevertheless, it was possible to obtain a measurable yield of hydroxyl radicals; see Fig. $6(\mathrm{~b})$. The reaction was inhibited by catalase (Fig. 6c), which will deactivate $\mathrm{H}_{2} \mathrm{O}_{2}$ before the Fenton reaction can take place.

\section{DISCUSSION}

\section{The complete pathway}

The secretion of $\mathrm{CDH}$ by the brown-rot fungus $C$. puteana provides a mechanism for $\mathrm{Fe}(\mathrm{II})$ production in the presence of oxalate (see Fig. 2). The reaction requires a much lower $\mathrm{pH}$ than that of wood itself. Brown rots lower the local pH. At low $\mathrm{pH}, \mathrm{Fe}$ (II) is resistant to autoxidation and may have a lifetime of an hour or more (see Fig. 4). Throughout its lifetime, $\mathrm{Fe}$ (II) will not be static. It will move by diffusion, as for any species of the same size. It also has an exchange reaction with $\mathrm{Fe}$ (III). The rate constant is not known for all species of interest, but one example is $k=4.25 \times 10^{3} \mathrm{M}^{-1} \mathrm{~s}^{-1}$ for $\mathrm{Fe}^{2+}$ and $\mathrm{Fe}^{\mathrm{III}}(\mathrm{ox})_{2}^{-}$(Horne, 1960):

$$
\mathrm{Fe}_{\mathrm{A}}^{2+}+\mathrm{Fe}_{\mathrm{B}}(\mathrm{ox})_{2}^{-} \rightarrow \mathrm{Fe}_{\mathrm{A}}(\mathrm{ox})_{2}^{-}+\mathrm{Fe}_{\mathrm{B}}^{2+}
$$

If one partner is present at $50 \mu \mathrm{M}$, the pseudo-first-order rate constant for this reaction will be $0.2 \mathrm{~s}^{-1}$, implying a half-life of about $3.5 \mathrm{~s}$. This is very much faster than the timescale of autoxidation and will greatly accelerate mobility. Diffusion of $\mathrm{Fe}$ (II) away from the hyphae brings it to a higher $\mathrm{pH}$ and promotes autoxidation. The complete pathway, including reaction of $\mathrm{H}_{2} \mathrm{O}_{2}$ with unoxidized $\mathrm{Fe}(\mathrm{II})$, is shown in Fig. 7. The diffusible

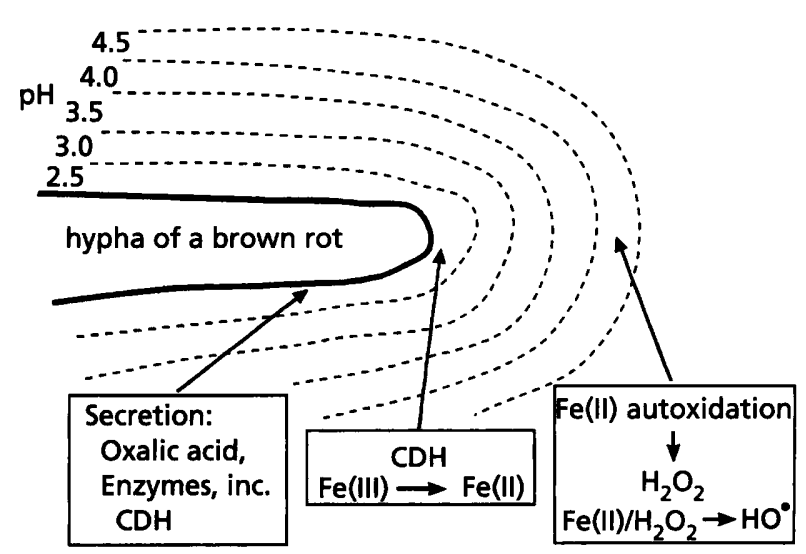

Fig. 7. Model for hydroxyl radical production without damage to the hyphae. 
Table 2. Mechanisms proposed for hydroxyl radical production by brown rot fungi

\begin{tabular}{|c|c|c|c|}
\hline Reference & Species & Source of $\mathrm{Fe}(\mathrm{II})$ & Source of $\mathrm{H}_{2} \mathrm{O}_{2}$ \\
\hline Schmidt et al. (1981) & (General model) & $\begin{array}{l}\text { Spontaneous decomposition of } \mathrm{Fe}(\mathrm{III}) \\
\text { oxalate }\end{array}$ & Secreted by the fungus \\
\hline Enoki et al. (1992) & $\begin{array}{l}\text { Gloeopbyllum } \\
\text { trabeum }\end{array}$ & $\begin{array}{l}\mathrm{Fe}(\mathrm{III}) \text { glycopeptide reduction by superoxide } \\
\text { (from } 1 \mathrm{e}^{-} \text {reduction of } \mathrm{O}_{2} \text { ) }\end{array}$ & $\begin{array}{l}\mathrm{O}_{2} \text { reduction by secreted NADH or } \\
\text { ascorbate, with Fe-glycopeptide } \\
\text { as catalyst }\end{array}$ \\
\hline Hirano et al. (1995) & Tyromyces palustris & $\begin{array}{l}\mathrm{Fe} \text { (III) reduction on binding to the chelator; } \\
\mathrm{Fe} \text { (III) can also be reduced by superoxide }\end{array}$ & As Enoki et al. (1992) \\
\hline This paper & Coniophora puteana & $\mathrm{Fe}$ (III) oxalate reduction by $\mathrm{CDH}$ & $\begin{array}{l}\text { Autoxidation of } \mathrm{Fe}(\mathrm{II}) \text { oxalate, } \\
\text { promoted by diffusion of } \mathrm{Fe}(\mathrm{II}) \\
\text { away from the hyphae }\end{array}$ \\
\hline
\end{tabular}

species is the extra electron on $\mathrm{Fe}(\mathrm{II})$, given the importance of $\mathrm{Fe}(\mathrm{II}) / \mathrm{Fe}$ (III) exchange.

\section{The mechanism of Schmidt et al. (1981)}

Table 2 presents a summary of the sources of $\mathrm{Fe}(\mathrm{II})$ and $\mathrm{H}_{2} \mathrm{O}_{2}$ in brown rot, as proposed by different authors. In the original mechanism of Schmidt et al. (1981), $\mathrm{Fe}$ (II) is formed by spontaneous decomposition of $\mathrm{Fe}$ (III) oxalate. However, evidence was presented in Fig. 1 for this being a light-dependent reaction. This photosensitivity of $\mathrm{Fe}$ (III) oxalate has a long history. Thus $\mathrm{Fe}$ (III) oxalate solutions can be used as an actinometer for measuring total exposure to light (Hatchard \& Parker, 1956), while the blueprint reprographic process employed paper impregnated with $\mathrm{Fe}$ (III) oxalate and potassium ferricyanide and gave a negative image due to lightdependent formation of Prussian blue (Grayson, 1982). The non-enzymic breakdown of $\mathrm{Fe}$ (III) oxalate may be of importance for fungal response to light, but cannot provide a general mechanism for timber decay. The mechanism of Schmidt et al. (1981) also presumed that $\mathrm{H}_{2} \mathrm{O}_{2}$ was secreted by the fungus, on the basis of experiments of Koenigs (1972, 1974a). In fact, Koenigs' results can be explained equally well by an indirect mechanism for $\mathrm{H}_{2} \mathrm{O}_{2}$ production, as proposed in Fig. 7 . In this respect, there may be a fundamental distinction between brown-rot and white-rot fungi. In white rots, the $\mathrm{H}_{2} \mathrm{O}_{2}$ required for lignin and $\mathrm{Mn}$ peroxidases is provided by oxidases, with substrates that include glucose and methanol (Eriksson et al., 1990). Such oxidases have not been reported for the standard brown rots. If $\mathrm{Fe}$ (II) is important in brown rot as a longdistance mediator, there is a need to avoid production of $\mathrm{H}_{2} \mathrm{O}_{2}$ close to the hyphae.

\section{Which comes first - oxygen reduction to superoxide, or $\mathrm{Fe}$ (III) reduction to $\mathrm{Fe}(\mathrm{II})$ ?}

In the mechanisms of Enoki et al. (1992) and Hirano et al. (1995), $\mathrm{O}_{2}$ reduction to superoxide is regarded as the initial step (see Table 2). This pathway for $\mathrm{HO}^{\circ}$ formation has been denoted the 'superoxide-assisted
Fenton reaction' (Halliwell \& Gutteridge, 1989) and is important inside living organisms, where almost all iron is in complexes that take no part in Fenton chemistry. However, if iron is mainly in low-molecular-mass complexes (as all the studies in Table 2 assume), direct reduction of $\mathrm{Fe}$ (III) is likely to be important. $\mathrm{Fe}$ (II) offers more scope than superoxide for movement by diffusion, since superoxide will always be subject to decay by dismutation.

\section{The source of reductant}

The models of Enoki et al. (1992) and Hirano et al. (1995) require the presence of NADH or ascorbate as reductant. However, there seems to be no evidence that such species are released from fungal cells. $\mathrm{Lu}$ et al. (1994) and Hirano et al. (1995) also report that $\mathrm{Fe}(\mathrm{III})$ is reduced to $\mathrm{Fe}(\mathrm{II})$ on binding to a phenolate chelator. This poses the question - is there a mechanism for regenerating the reduced form of the chelator? The source of reductant ceases to be a problem if $\mathrm{Fe}$ (III) reduction is catalysed by $\mathrm{CDH}$, since cellodextrin substrates will be provided by cellulases. One must therefore ask, is $\mathrm{CDH}$ widely distributed in brown rots? The chief negative evidence has been tests by Ander $\&$ Eriksson (1978), who used five species. Since one of these five species was C. puteana, a reappraisal is necessary. Our mechanism can also be criticized on the grounds that $\mathrm{Fe}$ (III) oxalate reduction by $\mathrm{CDH}$ is a relatively slow process, even at $\mathrm{pH} 2.5$ (see Fig. 2). This points to a need to search for alternative mechanisms for $\mathrm{Fe}$ (III) reduction. We cannot claim to have definitive answers to the questions posed in the Introduction, but hope the hypothesis in Fig. 7 will be useful for further work.

\section{The iron chelator}

This study has assumed that oxalate is the physiological iron chelator, in the absence of evidence to the contrary for C. puteana. The large resource of thermodynamic data for oxalate complexes has enabled the paradox of hydroxyl radical production without damage to the hyphae to be explained for the first time. It will be 
important to test whether stronger iron-complexing agents are also present, as proposed for Gloeophyllum trabeum and Tyromyces palustris (see Table 2). Regardless of the iron chelator, our results show the importance of considering $\mathrm{Fe}$ speciation and $\mathrm{Fe}(\mathrm{II})$ stability as a function of $\mathrm{pH}$.

\section{ACKNOWLEDGEMENTS}

We are grateful to L. M. Webb and Professor D. R. Williams (University of Wales, Cardiff) for assistance in speciation computations. This research was supported by the UK Biotechnology and Biological Sciences Research Council.

\section{REFERENCES}

Allison, J. D., Brown, D. S. \& Novo-Gradac, K. J. (1990). MINTEQA2/PRODEFA2: a Geochemical Assessment Model for Environmental Systems: Version 3.0 User's Manual. Athens, GA: Environmental Research Laboratory, US Environmental Protection Agency.

Ander, P. (1994). The cellobiose-oxidizing enzymes CBQ and $\mathrm{CbO}$ as related to lignin and cellulose degradation - a review. FEMS Microbiol Rev 13, 297-312.

Ander, P. \& Eriksson, K.-E. (1978). Lignin degradation and utilization by microorganisms. Prog Ind Microbiol 14, 1-58.

Backa, S., Gierer, J., Reitberger, T. \& Nilsson, T. (1992). Hydroxyl radical activity in brown rot fungi studied by a new chemiluminescence method. Holzforschung 46, 61-67.

Bao, W., Usha, S. N. \& Renganathan, V. (1993). Purification and characterization of cellobiose dehydrogenase: a novel extracellular hemoflavoenzyme from the white-rot fungus Phanerochaete chrysosporium. Arch Biochem Biophys 300, 705-713.

Bard, A. J. (editor) (1982). Encyclopaedia of Electrochemistry of the Elements, vol. IX, part A, $\mathrm{Hg}, \mathrm{Fe}, \mathrm{H}$. New York: Marcel Dekker.

Brown, E. R. \& Mazzarella, J. D. (1987). Mechanism of oxidation of ferrous polydentate complexes by dioxygen. J Electroanal Chem 222, 192-210.

Burkitt, M. J. \& Gilbert, B. C. (1991). The autoxidation of iron(II) in aqueous systems: the effects of iron chelation by physiological, non-physiological and therapeutic chelators on the generation of reactive oxygen species and the inducement of biomolecular damage. Free Rad Res Comm 14, 107-123.

Cowling, E. B. (1961). Comparative biochemistry of the decay of sweetgum sapwood by white-rot and brown-rot fungi. Technical Bulletin no. 1258, US Department of Agriculture, Washington, DC.

Cowling, E. B. \& Brown, W. (1969). Structural features of cellulosic materials in relation to enzymatic hydrolysis. Am Chem Soc Adv Chem Ser 95, 152-187.

Cox, M. C., Rogers, M. S., Cheesman, M., Jones, G. D., Thomson, A. J., Wilson, M. T. \& Moore, G. R. (1992). Spectroscopic identification of the haem ligands of cellobiose oxidase. FEBS Lett 307 , 233-236.

Davies, C. W. (1962). Ion Association. Washington, DC: Butterworths.

Deneux, M., Meilleur, R. \& Benoit, R. L. (1968). Chélates du fer(III) avec des anions dicarboxylates. Can J Chem 46, 1383-1388.

Dutton, M. V., Evans, C. S., Atkey, P. T. \& Wood, D. A. (1993). Oxalate production by basidiomycetes, including the white-rot species Coriolus versicolor and Phanerochaete chrysosporium. Appl Microbiol Biotechnol 39, 5-10.
Enoki, A., Hirano, T. \& Tanaka, H. (1992). Extracellular substance from the brown-rot basidiomycete Gloeophyllum trabeum that produces and reduces hydrogen peroxide. Mater Org 27, 247-261.

Eriksson, K.-E. L., Blanchette, R. A. \& Ander, P. (1990). Microbial and Enzymatic Degradation of Wood and Wood Components. Berlin: Springer.

Espejo, E. \& Agosin, E. (1991). Production and degradation of oxalic acid by brown-rot fungi. Appl Environ Microbiol 57, 1980-1986.

Evans, C. S., Burns, P. J., Dutton, M. \& Brown, S. (1990). 2-Amino$4 N$-ureidopropionic acid (albizzine) and its oxalyl derivative in hyphae of Coniophora puteana. Phytochemistry 29, 2159-2160.

Falck, R. (1926). Über korrosive und destructive Holzzersetzung und ihre biologische Bedeutung. Ber Deutsch Bot Ges 44, 652-664.

Grayson, M. (editor) (1982). Kirk-Othmer Encyclopaedia of Chemical Technology, 3rd edn, vol. 20. New York: John Wiley.

Green, F., Larsen, M. J., Winandy, J. E. \& Highley, T. L. (1991). Role of oxalic acid in incipient brown-rot decay. Mater Org 26, 191-213.

Grootveld, M. \& Halliwell, B. (1986). An aromatic hydroxylation assay for hydroxyl radicals utilizing high-performance liquid chromatography. Free Rad Res Commun 1, 243-250.

Halliwell, B. \& Gutteridge, J. M. C. (1989). Free Radicals in Biology and Medicine, 2nd edn. Oxford: Oxford University Press.

Hatchard, C. G. \& Parker, C. A. (1956). A new sensitive chemical actinometer. II. Potassium ferrioxalate as a standard chemical actinometer. Proc R Soc Lond A 235, 518-536.

Highley, T. L. (1977). Requirements for cellulose degradation by a brown-rot fungus. Mater Org 12, 25-36.

Hirano, T., Tanaka, H. \& Enoki, A. (1995). Extracellular substance from the brown-rot basidiomycete Tyromyces palustris that reduces molecular oxygen to hydroxyl radicals and ferric iron to ferrous iron. Mokuzai Gakkaishi 41, 334-341.

Horne, R. A. (1960). The kinetics of the oxalate catalysis of the iron(II)-iron(III) electron-exchange reaction in aqueous solution. $J$ Phys Chem 64, 1512-1517.

Illman, B. L., Meinholtz, D. C. \& Highley, T. L. (1989). Oxygen free radical detection in wood colonized by the brown-rot fungus Postia placenta. Biodeter Res 2, 497-509.

Kirk, T. K. (1983). Degradation and conversion of lignocelluloses. In The Filamentous Fungi, vol. 4, Fungal Technology, pp. 266-295. Edited by J. E. Smith, D. R. Berry \& B. Kristiansen. London: Edward Arnold.

Kirk, T. K., Ibach, R., Mozuch, M. D., Conner, A. H. \& Highley, T. L. (1991). Characteristics of cotton cellulose depolymerized by a brown-rot fungus, by acid, or by chemical oxidants. Holzforschung 45, 239-244.

Koenigs, J.W. (1972). Production of extracellular hydrogen peroxide and peroxidase by wood-rotting fungi. Phytopathology 62, 100-110.

Koenigs, J.W. (1974a). Production of hydrogen peroxide by wood-rotting fungi in wood and its correlation with weight loss, depolymerization and $\mathrm{pH}$ changes. Arch Microbiol 99, 129-145.

Koenigs, J. W. (1974b). Hydrogen peroxide and iron: a proposed system for decomposition of wood by brown-rot basidiomycetes. Wood Fibre 6, 66-80.

Kremer, S. M. \& Wood, P. M. (1992a). Continuous monitoring of cellulose oxidation by cellobiose oxidase from Phanerochaete chrysosporium. FEMS Microbiol Lett 92, 187-192. 
Kremer, S. M. \& Wood, P. M. (1992b). Evidence that cellobiose oxidase from $P$. chrysosporium is primarily an $\mathrm{Fe}(\mathrm{III})$ reductase: kinetic comparison with neutrophil NADPH oxidase and yeast flavocytochrome $b_{2}$. Eur J Biochem 205, 133-138.

Kremer, S. M. \& Wood, P. M. (1992c). Production of Fenton's reagent by cellobiose oxidase from cellulolytic cultures of Phanerochaete chrysosporium. Eur J Biochem 208, 807-814.

Lu, J., Goodell, B., Liu, J., Enoki, A., Jellison, J., Tanaka, H. \& Fekete, F. (1994). The role of oxygen and oxygen radicals in the one-electron oxidative reactions mediated by low-molecular weight chelators isolated from Gloeophyllum trabeum. International Research Group on Wood Preservation Document IRG/WP 94-10086. Stockholm: IRG Secretariat.

Martell, A. E. \& Smith, R. M. (1977). Critical Stability Constants, vol. 3, Other Organic Ligands. New York: Plenum Press.

Micales, J. A. \& Highley, T. L. (1989). Physiological characteristics of a non-degradative isolate of Postia (= Poria) placenta. Mycologia 81, 205-215.

Micskei, K. (1987). Equilibria in aqueous solutions of some iron(II) complexes. J Chem Soc Dalton Trans 255-257.

Morpeth, F. F. (1991). Cellobiose oxidoreductases. In: Chemistry and Biochemistry of Flavoenzymes, vol. 1, pp. 337-348. Edited by F. Müller. Boca Raton, FL: CRC Press.

Rayner, A. D. M. \& Boddy, L. (1988). Fungal Decomposition of Wood. Chichester: John Wiley.

Schaap, W. B., Laitinen, H. A. \& Bailar, J. C. (1954). Polarography of iron oxalates, malonates and succinates. J Am Chem Soc 76, 5868-5871.
Schmidhalter, D. R. \& Canevascini, G. (1992). Characterization of the cellulolytic system from the brown-rot fungus Coniophora puteana. Appl Microbiol Biotechnol 37, 431-436.

Schmidhalter, D. R. \& Canevascini, G. (1993). Isolation and characterization of cellobiose dehydrogenase from the brown-rot fungus Coniophora puteana. Arch Biochem Biophys 300, 559-563.

Schmidt, C. J., Whitten, B. K. \& Nicholas, D. D. (1981). A proposed role for oxalic acid in non-enzymatic wood decay by brown-rot fungi. Proc Am Wood-Preservers Assoc 77, 157-164.

Shimazono, H. (1955). Oxalic acid decarboxylase: a new enzyme from the mycelium of wood destroying fungi. $J$ Biochem 42, 321-340.

Wilcox, W. W. (1968). Changes in wood microstructure through progressive stages of decay. US Dep Agric For Serv Res Paper FPL-70.

Wood, P. M. (1988). The potential diagram for oxygen at $\mathrm{pH} 7$. Biochem J 253, 287-289.

Wood, P. M. (1994). Pathways for production of Fenton's reagent by wood-rotting fungi. FEMS Microbiol Rev 13, 313-320.

Zepp, R. G., Faust, B. C. \& Hoigne, J. (1992). Hydroxyl radical formation in aqueous solutions ( $\mathrm{pH} \mathrm{3-8)}$ of iron(II) with hydrogen peroxide: the photo-Fenton reaction. Environ Sci Technol 26, 313-319.

Received 21 May 1996; revised 19 August 1996; accepted 27 August 1996. 